\title{
Investigation in search of truth
}

\author{
Arye L. Hillman ${ }^{1} \cdot$ Heinrich W. Ursprung ${ }^{2}$
}

Received: 18 February 2020 / Accepted: 27 February 2020 / Published online: 9 March 2020 (c) Springer Science+Business Media, LLC, part of Springer Nature 2020

Academic economics is not always a quest for truth. Aesthetics can be expressed in formal theorems and assumptions of convenience allow amenable portrayals of the world in the form that economists and other social scientists would like the world to be. Peter Bernholz has spent his professional life in search of truth. His early days as a compelled member of Hitler Youth taught him that there are pressing issues to be addressed that derive from the coercion of the state and the denial of individual liberty. His expositions of economic issues do not include a benevolent dictator, as Kenneth Arrow, for example, would have required to solve his 'impossibility theorem'. Bernholz does not want a dictator. The assumed benevolence of dictators in economic models has had few realizations in the history of governance of men and women by other men and women. He dares tell us, through his concept of supreme values, that no benevolent solution of compromise may be possible when totalitarian ideologues challenge democratic values. He has contributed to other fields for which the practicalities of life are important. He has now reached his 90th year. This issue of Public Choice honors Peter Bernholz on the occasion of his 90th birthday.

Peter Bernholz has collected his contributions on supreme values (Bernholz 2017, summarized in Hillman 2018) and monetary regimes and inflation (Bernholz 2003/2015) in two recent volumes of his past writings. The papers in his honor extend beyond these topics. The papers, classified as dealing with supreme values, monetary policy, the politicaleconomic system, and the political-economic process, encompass a range of topics for which Peter Bernholz has been instrumental in contributing founding ideas.

His study of supreme values has taught us that there is no hope for compromise with a supreme-value adversary so long as the adversary retains the supreme values (Bernholz 1993). Others have suggested thinking about 'carrots and sticks'. Carrots have been proposed as means of providing incentives to perpetrators of Islamic terror that make sticks unnecessary (see, for example, Frey 2004). Peter Bernholz never believed that Hitler and Stalin, or Islamic and other supreme-value leaders, were rabbits who could be placated with 'carrots'. Having been in Hitler Youth, by obligation and not choice, he began to see uncompromising evil at a young age. Carrots offered to Hitler through the betrayal of the Czechs did not prevent ongoing and further evil. In addition to the

Arye L. Hillman

arye.hillman@biu.ac.il

Heinrich W. Ursprung

heinrich.ursprung@uni-konstanz.de

1 Bar-Ilan University, Ramat Gan 5290002, Israel

2 University of Konstanz, 78467 Constance, Germany 
Third Reich, Peter Bernholz has identified various supreme-value systems throughout history. He was concerned by how the National Socialists could have come to power in Germany. He also studied (Bernholz 1985) how conflict among countries could be prevented by coalitions that form to make pursuit of aggression unattractive. He has been forthright in pointing out (Bernholz 2004, 2006) that the supreme values of Islam are directed at achieving global Islamic domination.

A topic that Peter Bernholz has revisited consistently is monetary theory, in combination with policy and history. His doctoral dissertation refined the Austrian theory of capital. The objective was to explain the origin of interest. Later on, he devoted himself to topics such as the question of why fiat money is valued and the causes and consequences of inflations. As the root causes of hyperinflations, he identified political processes and the design of monetary regimes. Among the consequences of expansionary monetary shocks, he showed, by referring to historical evidence, that the overshooting of flexible exchange rates, which after the demise of the Bretton Woods system in the 1970 s attracted so much attention in the economics profession, could have been anticipated, had the 'experts' of the day not forgotten (or had they learned) the lessons available from their predecessors (Bernholz 1982a; Bernholz et al. 1985). In various travels in the 1980s to Argentina, Brazil, Bolivia, Chile and Ecuador, and outside of Latin America to Israel, he followed up his earlier studies on hyperinflations by collecting additional data and exchanging his views with local specialists. His research on hyperinflations, which extended over 25 years, culminated (Bernholz 2003) in a summary of what he had discovered. His attention to monetary history resulted in his contributions of chapters for the festschrift of the German Bundesbank (Bernholz 1998) commemorating the 50th anniversary of the German mark and the 100th anniversary festschrift of the Swiss National Bank (Bernholz 2007).

Peter Bernholz's research interest in political-economic relationships can be traced back to the time when he worked on his habilitation, which was at that time a prerequisite in Germany for applying for a professorship. The first draft of his habilitation thesis explored how international economic relationships can be applied to achieving foreign policy aims. He used arguments that subsequently came to be known as public choice theory. With that type of interdisciplinary research not finding favor with the mainstream of the 1950s, he had to rewrite his thesis for acceptability by the traditionally minded members of the faculty. A few years later, in 1963, when in the United States visiting Harvard University as a Rockefeller fellow, he met Anthony Downs, Mancur Olson and Gordon Tullock, and felt vindicated in his independently inspired 'public-choice' approach to exploring politicaleconomic systems. His first true public choice paper (Bernholz 1966) was on economic policies in a democacy. In the 1970s, when he was a professor at the University of Basel, he wrote a three-volume political economy textbook (Bernholz 1972, 1975, 1979) that was a reaction to the European student protests of 1968, which he had experienced in Berlin during his first appointment as a professor. His intent was to counter the Marxist ideologies to which many students at that time were attracted (including the second editor of this special issue who, however, changed his views when experiencing in the course of his studies a level of cognitive dissonance that no longer was sustainable - and that was even before Peter Bernholz asked him to proofread the last of the three volumes and to ready the figures for printing).

Peter Bernholz's work on political-economic systems is multifaceted. He revisited some of those topics again and again. Systems competition as a catalyzer for innovation and as a safeguard against excessive state power is a case in point (Bernholz et al. 1998). Another facet, which points to his longstanding friendship with James Buchanan, consists of his 
proposals for constitutional reform, in general (Bernholz 1979, 1991; Bernholz et al. 2004) and specifically constitutional monetary reform (Bernholz 1986, 2001a, 2013).

The pros and cons of designs of political-economic systems can be properly appreciated only when one understands the mechanisms that link a system's institutional details to its resulting operational mode. Peter Bernholz's studies of the overall performance of political-economic systems always were grounded in meticulous knowledge of the working of the political-economic process. He investigated rather than making assumptions. Perhaps the best known of his contributions to the understanding of the political-economic process deals with the issue of vote trading or logrolling (Bernholz 1973, 1982b, 1997). The message that resulted can be summarized in the Bernholz logrolling theorem: Whenever a collective decision involving several issues results from the independent decisions of subgroups that have the right to decide on each of those issues, and the collective decision can be overturned to the benefit of a winning coalition formed from among those subgroups, then intransitive social preferences are present. That result is just as eye-opening and informative as the message of the related Arrow and Gibbard-Satterthwaite impossibility theorems and the McKelvey-Schofield chaos theorem, which are with good reason hailed as the cornerstones of social choice theory.

In the domain of real affairs, Peter Bernholz served on several political advisory boards. He was not surprised to see a basic insight from public-choice theory confirmed: that governments rarely follow up well-founded theory- and evidence-based proposals that are not in line with reelection objectives. His memberships on the Scientific Advisory Council of the German Ministry of Economics and Energy, on an informal advisory group invited by the Directorate of the Swiss National Bank, and on the Macroeconomic Policy Group of the European Community, provided him with opportunities to apply his public-choice expertise in presenting his ideas in ways that were least likely to confront the resistance that could be met from self-interested politicians.

The principles of political economy or public choice have not been part of the mainstream of European economic thinking. Rather, views of the left have traditionally been popular in European academic circles. We have described instances (Hillman and Ursprung 2016) in which deviating from mainstream thought has been personally costly. Some bravery is required not to conform. Peter Bernholz is to be credited with disregarding the mainstream by being instrumental in the founding of the European Public Choice Society. In 1972, when attending a meeting of the List Society in Frankfurt, he met Gordon Tullock again (their first meeting after the 1963 meeting in the U.S.). Elisabeth Liefmann-Keil and Bruno Frey also attended the Frankfurt meeting. These four people played hooky, went on a hike in the neighboring hills, and decided there to found the European Public Choice Society. At the first and founding meeting of the society in Basel (16-17 December 1972), Mrs. Liefmann-Keil was elected president. In January 1974, she was run over by a car when crossing a street. She never recovered and died in August 1975. Peter Bernholz became president of the Society, and organized further meetings in 1974, 1976, 1979, and 1980 that were all held in Basel (the second author had the pleasure of acting as the local organizer in 1979 and 1980). The 1981 meeting was locally organized in Florence by Matthias Wolf, who was another PhD student of Peter Bernholz and was at the time visiting the European Institute in Fiesole (Florence). The 1982 meeting was organized by Charles Rowley in Oxford, who then became president (until the end of the century, the local organizer became president). Peter Bernholz was thus the first organizer of a European Public Choice meeting, the second president with also the longest term in office (1974-1981), and the president who can be credited with turning the Society in a truly European organization and an academic success. The 
conferences of the Society have continued successfully to the present day. In academic organization, he has also been active in the Mont Pelerin Society, for which he served for many years as the chairman of the admissions committee and as a board member.

Peter Bernholz has been the patron of the annual Silvaplana Workshop in Political Economy, which began in 1989 as a means of introducing ideas of public choice and political economy to advanced students who may not have been exposed to the existence of an alternative to the ideological and often emotional devotions of their proudly-onthe-left advisors and teachers. The papers in this issue were presented at the 28th annual Silvaplana Workshop held in Pontresina (Switzerland) in July 2019. At the Workshop, over the years, Peter Bernholz showed participants, through his critical questioning of presenters, that truth and relevance are more important than appeasement of an academic mainstream-or convoluted treatments of readily explainable economic and political phenomena.

We came to know Peter Bernholz in different ways. The second editor was a student of Peter Bernholz at the University of Basel but we and Peter Bernholz came together in 1987 when both of us were on longer-term stays at UCLA and Peter Bernholz came for a short visit. Our meetings involved discussions of issues of economics and politics but also Peter Bernholz introduced us to the game of Diplomacy, which is based on power relationships among European countries before the First World War. The game involves participants playing roles of countries and making commitments to other participants to form and sustain coalitions. Confidential sequential bilateral negotiations among participants in the game take place before actions are taken. Playing the game teaches the value of reputation for keeping promises. Not keeping promises can however be the way of winning the game, which teaches being wary of promises that do not coincide with the self-interest of those making the promises.

Peter Bernholz never hid his having been in Hitler Youth. The membership in Hitler Youth could have brought discomfort to the first editor, whose siblings were murdered as small children at Auschwitz by Hitler's helpers (who have been studied by Goldhagen 1996). Perhaps there was initial apprehension but discomfort never arose. It was clear that being in Hitler Youth was obligatory (a law in 1936 had made membership compulsory for 'Aryans'). Not conforming would have been personally costly and costly for family members. Hitler Youth was the foundation for Peter Bernholz distrusting the State as empowering individuals to control and harm others.

Peter Bernholz as a consequence of his experiences and contemplations has been interested not in what enlightened government could do, but in what political decision makers actually did. His thinking has never diverged far from the unifying question of how to ensure a free society. At heart, he may be an anarchist. He has always seen the institutions of the state as dangerous enemies of personal liberty. He feared that increasing regulation of economic activity would undermine democracy (2001b). As a scholar, he does not, however, see any alternative to state power. He has made this clear in his considerations of how a free society might confront totalitarian supreme-value adversaries (Bernholz 2004). He can see political failure, in politicians appeasing supreme-value regimes, allowing hyperinflations and increasing the powers of the state for their own vanity and control. His lifelong research agenda is a quest to identify institutional measures that can contain political and state power. It is therefore not surprising that he is a classical liberal (for Americans, libertarian) who endorses decidedly liberal policies of consolidating the rule of law, minimizing the discretionary power of public authorities, and reducing the size of the state sector, which imply correspondingly extending the scope of economic activities that take place in free, competitive, decentralized markets. 
We have learned from Peter Bernholz that age has no necessary correlation with the ongoing ability and willingness to think analytically. University bureaucrats may want academics to retire, because the bureaucrats themselves retire, and just as the bureaucrats want to free themselves from 'work', they perhaps suppose that the same applies to their scholarly underlings. A true intellectual, however, never retires. He or she would be retiring from thought and investigation. Peter Bernholz has demonstrated that an enquiring mind need not be squashed by bureaucratic impediments. There is, of course, a difference between Europe and other countries such as the United States or Australia. In Europe, consistent with perhaps a broader ideology, academics of a certain age are pushed out to 'create' jobs for others. In his investigations in search of truth, Peter Bernholz has refused to be shunted aside by European age discrimination.

On behalf of the Silvaplana group, we wish Peter Bernholz a productive continuation of his intellectual quests.

\section{References}

Bernholz, P. (1966). Economic policies in a democracy. Kyklos, 19(1), 48-80.

Bernholz, P. (1972, 1975, 1979). Grundlagen der politischen ökonomie. Tübingen: Mohr (Siebeck).

Bernholz, P. (1973). Logrolling, arrow paradox and cyclical majorities. Public Choice, 15, 87-95.

Bernholz, P. (1979). Freedom and constitutional economic order. Zeitschrift für die gesamte Staatswissenschaft [Journal of Institutional and Theoretical Economics], 135(3), 510-532.

Bernholz, P. (1982a). Flexible exchange rates in historical perspective. Princeton Studies in International Finance (Vol. 49). Princeton, NJ: Princeton University Press.

Bernholz, P. (1982b). Externalities as a necessary condition for cyclical social preferences. Quarterly Journal of Economics, 97(4), 699-705.

Bernholz, P. (1985). The international game of power: Past, present and future. Berlin: De Gruyter.

Bernholz, P. (1986). The implementation and maintenance of a monetary constitution. Cato Journal, 6, 477-511.

Bernholz, P. (1991). Constitutional aspects of the European integration. In S. Borner \& H. Grubel (Eds.), The European Community after 1992: Perspectives from the outside (pp. 45-60). London: MacMillan.

Bernholz, P. (1993). Necessary conditions for totalitarianism: Supreme values, power, and personal interest. In G. Radnitzky \& H. Bouillon (Eds.), Government: Servant or master (pp. 267-312). Amsterdam: Rodopi.

Bernholz, P. (1997). Property rights, contracts, cyclical social preferences and the Coase theorem: A synthesis. European Journal of Political Economy, 13, 419-442.

Bernholz, P. (1998). Die Bundesbank und die Währungsintegration in Europa. In Deutsche Bundesbank (Ed.), Fünfzig Jahre Deutsche Mark: Notenbank und Währung in Deutschland seit 1948 (pp. 773833). München: Beck.

Bernholz, P. (2001a). Monetary constitution, political-economic regime and long-term inflation. Constitutional Political Economy, 12, 3-12.

Bernholz, P. (2001b). Democracy and capitalism: are they compatible in the long-run? In D. C. Mueller \& U. Cantner (Eds.), Capitalism and Democracy in the $21^{\text {st }}$ Century. Proceedings of the International Joseph A. Schumpeter Society Conference, Vienna (pp. 9-22). Berlin and Heidelberg: Physica.

Bernholz, P. (2003/2015). Monetary regimes and inflation: history, economic and political relationships (2nd ed.,). Cheltenham: Edward Elgar.

Bernholz, P. (2004). Supreme values as the basis for terror. European Journal of Political Economy, 20(2), 317-333.

Bernholz, P. (2006). International political system, supreme values and terrorism. Public Choice, 128(1-2), 221-231.

Bernholz, P. (2007). Die Nationalbank 1945-1982: Von der Devisenbann-Wirtschaft zur Geldmengensteuerung bei flexiblen Wechselkursen. In Schweizerische Nationalbank (Ed.), Die Schweizerische Nationalbank 1907-2007 (pp. 119-211). Zürich: Neue Zürcher Zeitung.

Bernholz, P. (2013). Independent central banks as a component of the separation of powers. Constitutional Political Economy, 24, 199-214. 
Bernholz, P. (2017). Totalitarianism, terrorism and supreme values: History and theory. Heidelberg: Springer.

Bernholz, P., Gärtner, M., \& Heri, E. (1985). Historical experiences with flexible exchange rates: A simulation of common qualitative characteristics. Journal of International Economics, 19(1-2), 21-45.

Bernholz, P., Schneider, F., Vaubel, R., \& Vibert, F. (2004). An alternative constitutional treaty for the European Union. Public Choice, 118, 451-468.

Bernholz, P., Streit, M., \& Vaubel, R. (1998). Political competition, innovation and growth: A historical analysis. Berlin and Heidelberg: Springer.

Frey, B. S. (2004). Dealing with terrorism: stick or carrot?. Cheltenham: Edward Elgar Publishing.

Goldhagen, D. J. (1996). Hitler's willing executioners: Ordinary Germans and the Holocaust. New York: Alfred A. Knopf.

Hillman, A. L. (2018). Review of Peter Bernholz. Totalitarianism, terrorism and supreme values: History and theory. Public Choice, 176(3), 567-571.

Hillman, A. L., \& Ursprung, H. W. (2016). Academic exclusion: Some experiences. Public Choice, 167(12), 1-20.

Publisher's Note Springer Nature remains neutral with regard to jurisdictional claims in published maps and institutional affiliations. 